Urszula Ostrowska*

Bydgoszcz

\title{
W labiryncie wolności i odpowiedzialności za słowo
}

\author{
„Wolność bez odpowiedzialności \\ prowadzi do destrukcji” \\ Mihaly Csikszentmihalyi
}

\section{Uwagi wprowadzające}

Wolność i odpowiedzialność stanowią jeden z głównych problemów refleksji etycznej, dotyczących ontologicznych podstaw działalności ludzkiej, ewidentnie zaświadczających o conditio humana człowieka ${ }^{2}$, zwłasz-

* Prof. zw. dr hab. Urszula Ostrowska jest emerytowanym profesorem Wydziału Pedagogiki i Psychologii Uniwersytetu Kazimierza Wielkiego w Bydgoszczy. Adres: Instytut Pedagogiki UKW, ul. Chodkiewicza 30, 85-064 Bydgoszcz; adres e-mail: urszula.ostrowska@wp.pl.

${ }^{1}$ Helmuth Plessner, autor dzieła zawierającego w tytule ów zwrot condito humana, wyraził przekonanie, że ,autointerpretacja i doświadczenie samego siebie dokonują się za pośrednictwem innych ludzi i rzeczy. Droga do wewnątrz wymaga punktu oparcia na zewnątrz" (zob. Helmuth Plessner, Pytanie o conditio humana: wybór pism, wybrał i wstępem opatrzył Zdzisław Krasnodębski, przeł. Małgorzat Łukasiewicz, Zdzisław Krasnodębski, Andrzej Załuska (Warszawa: Wydawnictwo PIW, 1988), 86). Warto w tym miejscu zaakcentować, iż będący w toku przygotowań IX Ogólnopolski Zjazd Pedagogiczny, który obradować będzie w dniach 21-23 września 2016 roku w Białymstoku pt.: Ku życiu wartościowemu. Idee - Koncepcje praktyki, sytuuje się w tej istotnej konwencji. I tak, Sekcja I Zjazdu, której to Prezydium jestem członkiem, zaprasza do interdyscyplinarnej refleksji nad życiem wartościowym w kontekście conditio humana człowieka XXI wieku (zob. http://9zjazd.ptp.uwb.edu.pl/?page_id=533 [dostęp 1.10.2015]). 
cza o jakości jego człowieczeństwa. Ścisły związek obu kategorii wyraża się przede wszystkim w tym, że świadomie podejmujący dobrowolne działania podmiot powinien zarazem przyjmować na siebie zobowiązanie odpowiedzialności za swoje postępowanie i za jego następstwa. Jakkolwiek można zgłębiać każdą z tych kategorii oddzielnie, to jednak istota problemu w przyjętej perspektywie rozważań skłania ku temu, aby eksplorując jedną z nich, odwoływać się do drugiej i versus ${ }^{2}$.

Niewątpliwie problematyka wolności i odpowiedzialności za słowo towarzyszy ludzkości od niepamiętnych czasów, nabierając szczególnego/specyficznego znaczenia w kontekście dziejowym, w którym się sytuuje. Ludzie współcześni, wywodzący się z ,wieku nieodpowiedzialności”3, także z „ery czasu wolnego", zwanej też „erą postindustrialną"4, zanurzeni w epoce określanej jako liberalna/neoliberalna - mimo że pozostawieni zostali samym sobie, doświadczając wielorakiej niepewności - to jednak nie są ostatecznie pozbawieni en bloc szansy na kreowanie nowej, wartościowej jakości życia. Inaczej rzecz ujmując, jeśli człowiek współczesny zechce rozumnie dostrzegać twórczy potencjał swego czasu, to może satysfakcjonująco doświadczać poczucia swej rozumnej wolności oraz pozostającej z nią w ścisłym związku odpowiedzialności.

\title{
Kwestia wolności i odpowiedzialności za słowo z perspektywy aksjologicznej
}

\begin{abstract}
„Wolność polega na tym, aby śmiało rozpatrywać każdą sytuację, w jaką wpakuje nas życie i brać na siebie wszelką wynikłą stąd odpowiedzialność"
\end{abstract}

Jean Paul Sartre

Podejmując problematykę wolności i odpowiedzialności za słowo z perspektywy aksjologicznej, w tytule przywołuję symbol labiryntu - archetyp

2 Zagadnienie wolności i odpowiedzialności rozważałam w kontekście doświadczania wartości edukacyjnych przy innej okazji (zob. Urszula Ostrowska, Doświadczanie wartości edukacyjnych w szkole wyższej (Bydgoszcz: Wydawnictwo Uczelniane Akademii Techniczno-Rolniczej w Bydgoszczy, 1998), 189-256).

${ }^{3}$ Zob. Józef Kozielecki, Koniec wieku nieodpowiedzialności (Warszawa: Wydawnictwo Jacek Santorski \& Co, 1995).

${ }^{4}$ Pomysłodawcą tej kategorii jest socjolog amerykański Daniel Bell, który stwierdził, że źródłem satysfakcjonującego kryterium i pożądanego zachowania społecznego 
znany niemal na całym świecie. Ową metaforę o znaczeniu tak samo skomplikowanym jak wzór architektoniczny budowli odznaczającej się bardzo zawiłym układem dużej liczby pomieszczeń i łączących je krętych ciągów korytarzy, stwarzających trudność dostępu do celu - odnoszę do homo loquens - człowieka posługującego się słowem/językiem i sytuującego się permanentnie od początku swego rozumnego istnienia aż po sam kres życia między wolnością a odpowiedzialnością za słowo. W istocie bowiem człowiek, niczym w labiryncie, doświadcza, że w toku rozumnego korzystania ze swej wolności i zarazem przyjmowania za swoje decyzje i postępowanie odpowiedzialności, dokonując wyborów, zwłaszcza egzystencjalnie znaczących, permanentnie doświadcza, iż niezwykle trudno mieć pewność, czy owe wybory są najbardziej właściwe z możliwych oraz dobrze rokują na przyszłość.

Metafora labiryntu najczęściej utożsamiana jest z rytuałem przejścia, poszukiwania duchowego centrum, dążenia do samopoznania, także do samorealizacji. W przypadku rozważania problematyki między wolnością a odpowiedzialnością za słowo ów rytuał przejścia od-do i versus jest znaczący $\mathrm{z}$ tej zwłaszcza racji, że nie ma prostych rozstrzygnięć w tej mierze, lecz każdorazowo nieunikniona jest wnikliwa refleksja, namysł, osąd. Niemniej jakość owych relacji wolność-odpowiedzialność za słowo zależy głównie od tego, co podejmujący owe decyzje człowiek nade wszystko uznaje i preferuje, a co odrzuca i potępia, do czego aspiruje, a co dezawuuje, słowem ściśle wiąże się z jakością miejsca, które indywiduum zajmuje w universum antroposfery aksjologicznej, ewidentnie zaświadczając w tenże sposób o statusie swego człowieczeństwa.

Wolność i odpowiedzialność za słowo jest odwiecznym niewyczerpalnym tematem, towarzyszącym człowiekowi w rozmaitych kontekstach od zarania ludzkości. Zarówno o sens wolności, jak i odpowiedzialności za słowo na przestrzeni dziejów toczą się spory filozoficzne. Obie kategorie skupiają wokół siebie wiele kontrowersji oraz przysparzają mnóstwo kłopotów w relacjach interpersonalnych, a także w życiu społecznym, najczęściej z powodu zniekształcania, wypaczania, zawężania, bagatelizowania tudzież nadinterpretacji czy wyolbrzymiania ich znaczenia.

Nie wdając się w szczegółowe rozważania terminologiczne, trzeba zauważyć, iż, najogólniej rzecz ujmując, wolność - w przeciwieństwie do

przestała być praca, a stał się styl życia (zob. Daniel Bell, Kulturowe sprzeczności kapitalizmu, thum. Stefan Amsterdamski (Warszawa: Wydawnictwo PWN, 1998), 24). 
odpowiedzialności - jest słowem najczęściej umieszczanym w słownikach politycznych, a także nanoszonym na sztandarach rewolucji, przewrotów, protestów, żądań. Zazwyczaj ludzie gotowi są czynić wszystko, aby ją zdobyć, bronić, zachować czy odzyskać.

W sferze moralności wolność oznacza możliwość podjęcia bądź zaniechania działania, jak również potencjalność wyboru dobra lub zła w rozumieniu własnym albo ogólnym i wreszcie ewentualność wyboru postawy, światopoglądu czy w ogóle sposobów postępowania. Z jednej strony wolność słowa gwarantowana jest przez konstytucyjne oraz ustawodawcze wolności obywatelskie (obok wolności osobistej, wolności sumienia i wyznania, wolności zgromadzeń, wolności zrzeszania się), z drugiej strony jest niekwestionowalnym prawem osobistym i niezbywalnym.

Niemniej zwrot „wolność słowa” i odpowiednio wyrażenie „odpowiedzialność za słowo" stanowią w istocie pewien skrót myślowy, obejmują bowiem swym zakresem znacznie więcej, niż owe wyrażenia na pierwszy rzut oka sugerują. Oto bowiem wielość zagadnień związanych z problemem „wolność słowa” odnosi się także do takich kategorii kluczowych, jak: wolność myśli, wolność wypowiedzi, wolność informacji, wolność prasy (freedom of thought, freedom of speech, freedom of expression, freedom of the Press) - i odpowiednio w odniesieniu do „odpowiedzialności za słowo” (resposibility of the words etc.).

Najogólniej rzecz ujmując, przedmiotem wolności słowa jest prawo do swobodnego wyrażania myśli, czyli wolność wewnętrzna indywiduum (libertas interna). Owa wolność odnosi się do prawa posiadania poglądów dotyczących najrozmaitszych przejawów otaczającej rzeczywistości. Wszelako myśli, poglądy, przekonania, stanowiska nieuzewnętrznione podlegają bezwzględnej ochronie (cogitationis poenam nemo patitur) jako że nie wolno wobec tych faktów, stanów rzeczy, procesów stosować jakiegokolwiek przymusu, wykluczając ewentualność zagrożeń wynikających z tychże zjawisk dla ich pomysłodawców tudzież dla innych osób. Rzecz jasna myśl jest niedostępna dla poznania wbrew woli tego, kto ją generuje, toteż z tej racji pozostaje ona poza zasięgiem skutecznego oddziaływania zewnętrznego. Niemniej wolność myśli ma pierwotny charakter, warunkujący de facto możliwość korzystania $\mathrm{z}$ wolności sumienia, a w konsekwencji także z wolności słowa oraz wolności wyznania. $Z$ racji przysługującego indywiduum prawa do wolnego posługiwania się owym przymiotem, wolność ta ma charakter absolutny i bezwarunkowy, ponieważ dotyczy kwestii wewnętrznych, w które wgląd en bloc jest bardzo ograniczony, raczej niemożliwy. Wolność słowa jest pochodną wolności myśli i oznacza zarówno wolność słowa sensu 
stricto, jak i odnosi się do innych rodzajów wolności funkcjonujących w zakresie różnych przejawów aktywności ludzkiej, w tym w zakresie swobodnego uzewnętrzniania przez człowieka własnych myśli (opinii, poglądów, stanowisk, przekonań, informacji) innym osobom w formie możliwej do percepcji (zazwyczaj postrzeganej w kategorii zrozumiałości).

Niemniej wolność słowa, jawiąc się jako największe dobro, skupia wokół siebie wiele nieporozumień, błędów, a nawet różnej miary ekstrawagancji i ekscesów, zwłaszcza wtenczas, kiedy - sytuowana poza odpowiedzialnością - jest nadużywana, przeradzając się w samowolę i prowadząc do destrukcji.

Wolność słowa nie oznacza oczywiście nieograniczonej wolności wypowiadania się. Częstokroć - zdawałoby się paradoksalnie - ograniczana bywa właśnie w imię wolności słowa i praw jednostki wówczas, gdy pewne poglądy i leksyka je naruszają. Za naruszanie wolności słowa innych osób można ponosić odpowiedzialność prawną. Jakkolwiek każdemu przysługuje prawo i obowiązek bronienia swoich stanowisk oraz wartości, którymi kieruje się w swoim życiu, to jednak nikt nie jest uprawniony do osiągania owego celu kosztem innych, zwłaszcza za sprawą głoszenia nieprawdy, stosowania podstępnych manipulacji, różnej miary stronniczości, partykularyzmu etc. Dotyczy to zwłaszcza tych osób, którym z racji przysługujących prerogatyw społecznych przysługuje więcej przywilejów niż innym. Lucjusz Anneusz Seneka uwrażliwiał na ów stan rzeczy, znacząco eksponując ścisłe związki wolności i odpowiedzialności, pisząc na ten temat: Minimum decet libere cui multum licet [Komu wolno wiele, temu najmniej przystoi być samowolnym $]^{5}$.

Natomiast w przypadku przypisywanej człowiekowi odpowiedzialności za słowo, która jako atrybut przejawia się w sposób proceduralny, z jednej strony przejawiając się w przebiegu oraz $\mathrm{w}$ wynikających $\mathrm{z}$ niego konsekwencjach postępowania osoby, z drugiej strony natomiast ujawnia się zarazem subiektywnie - w wewnętrznym specyficznym poczuciu odpowiedzialności podmiotu, stanowiąc w swej istocie przeciwieństwo wszelkiej niefrasobliwości, nierzetelności, niesolidności, niekompetencji, lekkomyślności - owo zniekształcanie tudzież wypaczanie czy zawężanie znaczenia polega przede wszystkim na sprowadzaniu jej sensu li tylko do obowiązku bądź też na tak zwanym pociąganiu do odpowiedzialności wyłącznie za negatywne następstwa zachowań. Tymczasem człowiek jest odpowiedzialny i powinien przyj-

${ }^{5}$ Lucjusz Anneusz Seneka, Myśli, wybór, przekład i opracowanie Stanisław Stabryła (Kraków: Wydawnictwo Literackie, 1987), 556-577. 
mować odpowiedzialność za całokształt swojego postępowania - zarówno za pozytywne, jak i negatywne jego następstwa.

Niemniej jednak odpowiedzialność za słowo, powszechnie pojmowana jako istotna cecha człowieczeństwa, zarazem - paradoksalnie - bywa dość często odczuwana jako uciążliwość, a nawet ciężar czy dotkliwość, przed którą najchętniej próbuje się uciec bądź od której trzeba się uwolnić albo ewentualnie przerzucić ją na kogoś innego.

Prawdziwa odpowiedzialność, będąc wyłącznie typowo ludzkim atrybutem, ma swoje wyraźne usytuowanie aksjologiczne i odniesienie antroposferyczne. Ponosić odpowiedzialność, być autentycznie odpowiedzialnym może tylko osoba świadoma swego działania i tylko wówczas, kiedy te działania są jej własnymi, to znaczy, gdy wypływają wprost - jak to ujął Roman Ingarden w Ksiażeczce o czlowieku: ,z centrum [...] «ja», kiedy podmiot panuje nad dokonaniem wyłaniającego się z niego działania i kieruje nim".6.

Warunkiem zaistnienia prawdziwej odpowiedzialności jest świadoma dobrowolność tego aktu, co wyeksponował następująco między innymi Erich Fromm: „Odpowiedzialność w swym prawdziwym znaczeniu jest aktem całkowicie dobrowolnym, jest moją potrzebą zaspokajania wyrażonych lub niewyrażonych potrzeb drugiej istoty ludzkiej. Być «odpowiedzialnym»znaczy być zdolnym i gotowym do «odpowiadania» na ten apel"7.

Również wolność należy do tych pojęć, które skupiają wokół siebie wiele kontrowersji oraz definicji. Niemniej jednak w gąszczu bez mała 200 określeń tego pojęcia Isaiah Berlin w klasycznym eseju na temat wolności rozróżnia tylko dwa jego zasadnicze znaczenia, a mianowicie wolność negatywną OD i wolność pozytywną DO. Wolność negatywna pojmowana jest liberalnie jako brak zakazów i nakazów sprzeciwiających się woli jednostki (z wyjątkiem tzw. uwarunkowań naturalnych, tj. warunków geograficznych, przyrody, klimatu tudzież zdeterminowanych konstrukcją psychofizyczną własnej natury, choć tego typu ograniczenia w różnym stopniu i zakresie możliwe są do przezwyciężenia np. za sprawą usilnej pracy nad sobą). Z drugiej strony wolność częstokroć ograniczana bywa czynnikami zewnętrznymi, w tym zwłaszcza trudnymi do sprecyzowania kryteriami tak zwanego dobra ogólnego, jak również obowiązującym prawem libertas in legibus (wolność pod opieką prawa). Człowiek, jako część ekosystemu oraz zbiorowości spo-

${ }^{6}$ Roman Ingarden, Książeczka o człowieku (Kraków: Wydawnictwo Literackie, 1987), 85.

${ }^{7}$ Erich Fromm, Niech się stanie czlowiek. Z psychologii etyki, thum. Robert Saciuk (Warszawa: Wydawnictwo PWN, 1994), 33. 
łecznych, nie jest i nie może być absolutnie/całkowicie wolny, niezależny, lecz tylko w pewnym stopniu, czyli w jakiejś części. Całkowita wolność możliwa jest do zaistnienia tylko w wyobraźni, w teorii, jako że żadna istota ludzka nie istnieje w oderwaniu od środowiska, społeczeństwa, niezależnie od doświadczającego przez nią poczucia wolności.

Owo negatywne określenie wolności OD, ze względu swego jednostronnego wymiaru, wymaga uzupełnienia/dookreślenia, czemu wychodzi naprzeciw drugie znaczenie wolności, to jest wolność pozytywna DO podmiotu wewnątrzsterownego, dysponującego racjonalną naturą $\mathrm{w}$ zakresie dokonywanych przez niego wyborów, w tym wolnością do obierania jedynie słusznej drogi życia.

Rozważanie z perspektywy aksjologicznej kwestii wolności i odpowiedzialności za słowo pozwala na wyłonienie co najmniej kilku wymiarów owej problematyki, które $\mathrm{w}$ istocie swej przybierają postać kręgów problemowych, ogniskujących wokół preferowanego przez podmiot systemu wartości uniwersum antroposferycznego, co można zilustrować graficznie (Ryc. 1.). Owe kręgi w różnym stopniu i zakresie wzajemnie warunkują się, uzupełniają i weryfikują.

Ryc. 1. Kręgi problemowe wolności i odpowiedzialności za słowo

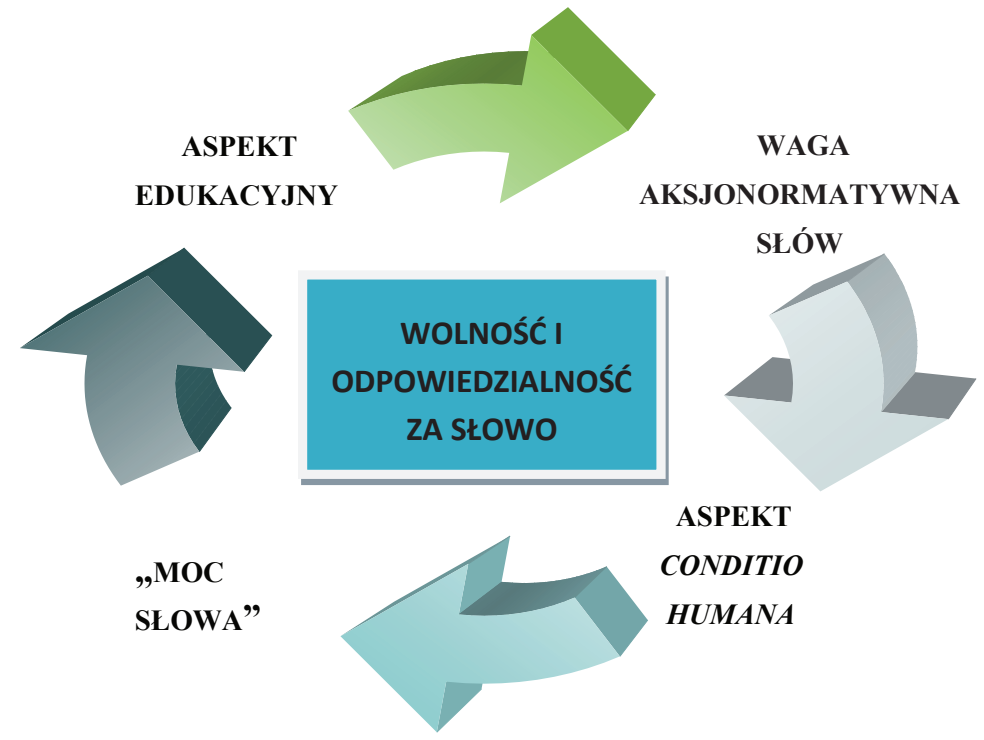




\title{
A/ Rozpocznę od kręgu problemowego „mocy słowa” jako że słowo zdolne jest pokierować czlowiekiem w najbardziej ludzki i nieludzki sposób, a jego użycie nie pozostawia ludzi niewinnymi.
}

\begin{abstract}
„[...] słowo jest materią tak twardą jak kamień. I pokrewną kamieniowi. [...] Zanim odejdziesz do innego świata, masz tu przemienić się w słowa. Takie, które po tobie zostaną wśród ludzi”
\end{abstract}

Boecjusz

W toku dziejów na rolę i znaczenie słowa spoglądano wszakże z różnej perspektywy, poddając wywody rozmaitym interpretacjom sytuowanym w kolejnych wcieleniach myśli ludzkiej w jej rozwoju. Od Hellenów wywodzi się podzielane i rozwijane przez późniejszych humanistów przekonanie, że słowo ${ }^{8}$ jest przemożnym mocarzem, zdolnym pokierować czlowieka zarówno w kierunku najwyższego dobra, jak i najgorszego zła 9 .

Wolność słowa daje człowiekowi przywilej nietelosującego ${ }^{10}$ korzystania z bogatego słownictwa, nieograniczającego swej roli li tylko do porozumiewania się, kontaktowania się osób, lecz także w różnym stopniu i zakresie wzbogacania go za sprawą wyrażania swoich myśli i uczuć jako specyficznie człowieczego sposobu istnienia w świecie, zarazem wpływającego stymulująco na ludzkość aż do kreatywnego spełniania się w procesie tworzenia niespetryfikowanych form językowych oraz rozległego horyzontu interpersonalnego komunikowania się włącznie. Uzasadnianiu wolności słowa zazwyczaj przewodzi założenie, iż swoboda wypowiedzi długofalowo gwarantuje więcej dobra niż szkody.

Oto bowiem człowiek potrzebuje przekuwać to, co myśli i czyni, w słowa, potrzebuje szeregować, określać i nazywać, jednakże z owej konfrontacji z językiem nigdy nie wychodzi bez szwanku. Słowa, łącząc się ze światem,

${ }^{8}$ Logos - ten starogrecki wyraz oznacza nie tylko słowo, lecz także pojęcie, myśl, rozum, czyli to, co ma związek z myśleniem, mową.

9 Dokładniej rozważałam tę problematykę między innymi w książce Dialog w pedagogicznym badaniu jakościowym (Kraków: Oficyna Wydawnicza Impuls, 2000).

${ }^{10}$ Słowa „nietelosującego” użyłam w znaczeniu: niemającego kresu. Husserl w tekście Kryzys europejskiego człowieczeństwa pisze m.in. o duchowym telosie, otwartym, niemającym końca horyzoncie, w którym człowiek żyje. 
wywołują określone następstwa, nie pozostawiając ludzi niewinnymi ${ }^{11}$, stąd nieodzowność przyjmowania odpowiedzialności za słowo.

Jakkolwiek kwestia wolności słowa postrzegana jest przede wszystkim za konstytutywny przywilej, to jednak nie zawsze przyjmowanie odpowiedzialności za słowo uznawane bywa za powinność moralną, stąd owo zjawisko przerzucania odpowiedzialności na innych, unikania odpowiedzialności tudzież ucieczki od odpowiedzialności.

\title{
B/ Kolejny wyłoniony krąg problemowy dotyczy wagi aksjonormatywnej słów.
}

\begin{abstract}
„Przede wszystkim trzeba [...] dobrze rozumieć znaczenie słów, aby, gdy sprowadzi się do nich nasze myśli, sądy i wątpliwości, można było rozstrzygnąć, aby wszystkie sprawy nierozstrzygnięte nie ciągnęły się w nieskończoność, albo abyśmy nie byli zmuszeni posługiwać się pustymi wyrazami”
\end{abstract}

Epikur

Tę kwestię dostrzegano już w starożytności, piętnując rozwlekłe spory, niewiodące do celu oraz trywialne dysputy, sprowadzające się do przechwałek o osobistej odwadze, czynach, przymiotach etc. Tymczasem okazuje się, że do dziś nadmiar słów niejednokrotnie zagraża ich jakości. Artykułując swoje myśli, ludzie nieczęsto bywają cyzelatorami słów i niejednokrotnie popełniają rażące błędy w tej sztuce, rozmaicie deformując swoje wypowiedzi. Oto bowiem, pokonując tu i ówdzie pojawiające się aporie, człowiek czasem może się mylić, mówić bez sensu, wypowiadać treści banalne, a nawet fałszywe. Zdarza się, że ludzie posługują się mową pełną komunałów, nudnych frazesów albo też usiłują wyrazić myśli bardziej złożone niż pozwalają im na to ich własne predyspozycje werbalne i intelektualne. Rażącą egzemplifikacją popadania w samowolę oraz sprzeniewierzania się odpowiedzialności za słowo jest manifestowanie postawy nierzetelności, kłamstwa, fałszu, braku dobrej woli, wprowadzania w błąd, upokarzania, manipulacji do tego

11 Pytanie ,jak słowa łączą się ze światem" postawił jeden trzech amerykańskich neopragmatystów Hilary Putman, zwracając uwagę na doniosły problem filozoficzny, który znamiennie absorbuje uwagę nie tylko współczesnych filozofów. 
stopnia nawet, że czasami trudno poddać owe przejawy rozstrzygającemu anagnoryzmowi ${ }^{12}$.

Pozostając w tym kręgu problemowym, warto jeszcze dodać, że kwestia wolności i odpowiedzialności za słowo nabiera szczególnego znaczenia $\mathrm{z}$ tej racji, iż w słowach może zawierać się najśmielsza konstrukcja oraz totalne unicestwienie. Słowa bowiem są z definicji ważne, szczególnie znaczące, niemal święte, przyjazne człowiekowi, ale słowa są również przepełnione jadem, goryczą, nienawiścią, wrogością, złem. Niemniej jednak nietrudno przekonać się, iż niemal każde słowo może być początkiem dla sacrum i dla profanum. Kwestia odpowiedzialności za słowo uwyraźnia się zwłaszcza z tej racji, że czasem wystarczy tylko jedno słowo, aby poruszyć intelekt, wzbudzić uczucia i zainspirować do wspaniałych, zdawałoby się bezkresnych, przedsięwzięć, albo zgoła przeciwnie - okaleczyć relacje ludzkie, zniechęcić całkowicie, zniweczyć, wręcz zabić w zarodku wszystko co najszlachetniejsze.

\section{C/ Trzeci wyłoniony krąg to kwestia wolności i odpowiedzialności za sło- wo w aspekcie conditio humana współczesnego człowieka}

„Wolność oznacza odpowiedzialność. A jest to właśnie to, czego większość ludzi się obawia"

George Bernard Shaw

Słowa składają się na uniwersalne medium - język - spełniający się w rozmowie, w dialogu, w dyskusji, w dyskursie - w ustrukturyzowanych sposobach komunikowania się przynależnych tylko człowiekowi, zaświadczając o statusie jego człowieczeństwa oraz odzwierciedlając sposób postrzegania i rozumienia przez indywiduum siebie samego, innych, otaczającą rzeczywistość. Zaiste o bezgranicznej wielkości leksyki zaświadcza fakt, że człowiek jako istota niewielka i zaledwie okresowo egzystująca na ziemi

12 Słowa ,anagnoryzm” użyto w znaczeniu „rozpoznanie” (trudno poddać rozstrzygającemu rozpoznaniu). Andrzej Szahaj w jednej ze swych najnowszych książek pt. Kapitalizm drobnego druku (Warszawa: Instytut Wydawniczy Książka i Prasa, 2014), zwraca uwagę na skrótową rekonstrukcję myślenia człowieka, który buduje swoje poczucie bycia kimś lepszym, tudzież zmierza ku osiąganiu poczucia władzy, pogardzając słabszymi bądź upokarzając innych. 
może za pomocą słowa ów nieprzenikniony świat niemal na wskroś ogarnąć, a poza tym jako indywiduum świadome potrafi niejednokrotnie w zdumiewający wręcz sposób wiele wyeksplikować, zrozumieć, zinterpretować, przekazać innym. Co więcej, homo sapiens może wnikliwie rozważać nawet to, co w ogóle nie istnieje, jak również w najśmielszych swych przedsięwzięciach tudzież ambitnych marzeniach projektować to, co wydaje się niemożliwe do spełnienia. W słowach bowiem zawarta jest potencjalność nigdzie niezdeterminowanej kreatywności z tego względu, że mają one $\mathrm{z}$ reguły transcendujący, rozległy horyzont, dla którego granice ewoluują, rozszerzając się w trakcie myślenia, komunikowania, porozumiewania się osób. Na dodatek nie są to granice ostateczne ani dla owych słów, ani dla osób, zaś sfera znaczenia nie da się w żaden sposób apriorycznie przewidzieć, czego dowodzi w toku dziejów, a zwłaszcza towarzyszące nam współcześnie przełamywanie, przekraczanie uznawanych konwencji w myśleniu, także w intersubiektywnym komunikowaniu się, aż do ewentualności kreowania nowych nieco/zupełnie elementów lingwistycznych czy rozległych struktur włącznie. $Z$ takiej perspektywy spoglądając, dostrzega się nieodzowność zagwarantowania wolności za słowo, z drugiej strony natomiast im większy wymiar przedsięwzięć aspirujących do twórczego wykraczania poza dotychczasowe osiągnięcia, tym ów „ciężar” odpowiedzialności nabiera większej wagi.

W tymże kręgu problemowym sytuuje się znacząco imperatyw moralny - „odpowiednie dać rzeczy słowo”, określający obowiązującą normę dla wolności i nierozerwalnie związanej z nią odpowiedzialności za słowo, co wyraża w etyce naczelna norma moralna, obowiązująca w sposób powszechny, bezwarunkowy i bezwzględny ${ }^{13}$.

Odpowiedzialność za słowo to atrybut człowieczeństwa, a nawet wręcz immanentna własność gatunkowa, jak również powinność nakładana na jednostkę oraz przez nią przyjmowana, o którą może ona się ubiegać w związku $\mathrm{z}$ pełnioną rolą. $\mathrm{Z}$ racji doświadczanej przez człowieka niepewności, swoistego rozdarcia co do słuszności podejmowanych decyzji, w tenże sposób przez pryzmat odpowiedzialności za słowo przejawia się kondycja człowieka - jego wielkość i siła, a zarazem może się objawiać w sposób nieunikniony jego kruchość i słabość. Owa niepewność bowiem określa człowieka wrażliwego, refleksyjnego, skłaniającego się do namysłu, otwartego na nową wiedzę i summa summarum stającego się bardziej ludzkim niż indywiduum

13 Cyprian Kamil Norwid nawołuje do tego, aby zawsze „odpowiednie dać rzeczy słowo”, z tej racji zwłaszcza, że jak uzasadniał: „Słowa nasze nas sądzą nie tylko wyrażają”. 
nad wyraz zadufane w sobie, mające przeświadczenie o swej bezwzględnej (zawsze) racji, będące w sposób nieuprawniony pewnym siebie, $\mathrm{z}$ reguły z pogardą odnoszące się do osób deklarujących odmienne od niego stanowiska, poglądy, przekonania.

D/ Ostatni z wyłonionych w niniejszych rozważaniach kręgów to problem wolności i odpowiedzialności za słowo $\mathbf{w}$ wymiarze edukacyjnym ${ }^{14}$.

„Ze słowa i z włożonego w nie rozumu czerpie człowiek niezwykłe siły poznania"

Ferdinand Ebner

Kwestia wolności i odpowiedzialności za słowo w edukacji bywa postrzegana jako zobowiązanie szczególne, przekraczające zasadę powinności i przybierające wymiar misji, posłannictwa z racji zwłaszcza możliwości wszechstronnego oddziaływania nauczycieli, wychowawców na uczniów, wychowanków, studentów. Odnosi się zatem nie tylko do kwestii formułowania własnych stanowisk, przekonań, poglądów, lecz także dotyczy uprzystępniania, przekazywania ich innym.

Wagę wolności i odpowiedzialności za słowo w wymiarze edukacyjnym uwyraźnia bez wątpienia fakt, że słowa pełnią główną rolę w procesach poznawczych ludzi i tak już zapewne pozostanie (także w epoce informacyjnej), skoro świat człowieka, od początku jego rozumnego istnienia aż po sam kres życia, jest światem pojęć, które są poznawane i rozumiane zgodnie z ich sensem, a w ślad za tym internalizowane oraz eksterioryzowane przez podmiot, albo wręcz odrzucane bądź też ich treść bywa zniekształcana i trywialnie wypaczana lub zgoła przeciwnie - twórczo wzbogacana przez indywiduum. Nie oznacza to bynajmniej, że niedająca się porównać z żadnym tworzywem twórczym tajemnicza dostojność słowa ${ }^{15}$ równocześnie rozwiązuje wszelkie

${ }^{14} \mathrm{Z}$ nieco innej perspektywy podejmowałam zagadnienie odpowiedzialności za słowo w edukacji (zob. Urszula Ostrowska, ,Axiological Aspects of the Word in Education”, Journal of International Scientific Publications 9 (2015), www. Scientific-publications.net) oraz w edukacji akademickiej (zob. Urszula Ostrowska, „Problem odpowiedzialności za słowo w edukacji akademickiej”, w: Odpowiedzialność jako wartość i problem edukacyjny, red. Andrzej M. de Tchorzewski (Bydgoszcz: Wydawnictwo „WERS”, 1998), 141-168.

15 Zdaniem Jana Parandowskiego „ani kamień, drzewo, metal, którymi posługuje się architektura i rzeźba, ani farby, którymi rozporządza malarstwo, ani dźwięki wydobyte z in- 
werbalne problemy. Otóż każdy człowiek jakoby asymiluje docierające do niego słowa w znacznej mierze na swój i tylko sobie właściwy sposób, to znaczy swoisty dla swojego aktualnego status quo sposób, toteż nic dziwnego, że nawet ta sama wypowiedź może być odbierana odmiennie i swoiście przetwarzana odpowiednio przez poszczególne jednostki.

Dla procesów edukacyjnych istotne jest, iż słowa od dawien dawna okazują się znamiennym probierzem istotnych atrybucji człowieka, w tym jego zdolności, poziomu wiedzy, kompetencji, umiejętności komunikacyjnych, mądrości.

Niemniej dla wszelkich odpowiedzialnych działań edukacyjnych istotne jest takie podejście nauczycieli/wychowawców do swoich powinności, aby nie naruszając status quo poczucia wolności, w tym autokreatywności uczniów/wychowanków/studentów, osiągać założone cele wzbogacania antroposfery i, dzięki poszerzaniu horyzontu aksjologicznego oraz z racji roztaczania rozległych perspektyw poznawczych, w rezultacie osiągać założone cele.

Wolność i odpowiedzialność za słowo w edukacji implikuje ethos nauczyciela/wychowawcy, a zaświadcza na co dzień logos. Fundamentalną podstawę dla wolności i odpowiedzialności za słowo stanowi, wynikający z całokształtu uznawanych i przestrzeganych przez nauczyciela/wychowawcę w praktyce edukacyjnej wartości, imperatyw dotyczący nie tylko prawdziwości i aktualności głoszonej w toku procesu edukacji wiedzy, ale także kształtowania świadomości pojmowania jej jako jednego z możliwych i bardzo ważnych sposobów opisywania i rozumienia rzeczywistości, sposobu, który zawiera nie tylko możliwości, ale także ograniczenia. Autorska prezentacja własnej oraz interpretacja cudzej wiedzy - rzecz oczywista - nie zwalnia nauczyciela/wychowawcy z obowiązku dystansowania się wobec subiektywnych preferencji, które mogą zniekształcać tudzież zaciemniać stan wykładanej dyscypliny, lecz nade wszystko zobowiązuje do odpowiedzialnego, w sposób zalecany przez Norwida w procesie edukacji, odpowiedniego dawania rzeczy słowa.

Warto w tym miejscu zauważyć, iż Jean-Paul Sartre, ujmując wolność szeroko jako daną wraz ze świadomością każdemu człowiekowi, który jest skazany na to, by być wolnym i zarazem całkowicie odpowiedzialnym za to co robi, wyznacza wolności charakter dydaktyczny z tej racji, że czło-

strumentów, które są materiałem twórczym muzyki, nie mogą porównać się z tajemniczym dostojeństwem słowa" (Jan Parandowski, Alchemia słowa (Warszawa: Wydawnictwo Czytelnik, 1986), 126). 
wiek musi się nieustannie uczyć swojej wolności, zwłaszcza poprzez własne czyny ${ }^{16}$.

Wyłonione kręgi, rzecz jasna, nie wyczerpują całokształtu ogniskującej wokół kwestii wolności i odpowiedzialności za słowo podjętej problematyki, lecz w zamyśle przede wszystkim sygnalizują jej wagę i złożoność, skłaniając ku pochylaniu się nad takimi ważnymi aspektami, jak na przykład wolność i odpowiedzialność za słowo w nauce, w mediach, w polityce i wielu innych.

\section{Uwagi na zakończenie}

„Słowo jest potęgą. Utrwalone w piśmie, zdobywa niedającą się obliczyć ani przewidzieć władzę nad myślą i wyobraźnią ludzi, panuje nad czasem i przestrzenią"

Jan Parandowski

Rozważając problem między wolnością i odpowiedzialnością za słowo i podążając tropem metafory labiryntu, zamierzałam wyeksponować, iż zanurzony w otaczającej rzeczywistości człowiek nieustannie doświadcza konieczności dokonywania wyborów w rozmaitości bycia, co niejako zmusza do urzeczywistniania przynależnej mu wolności. Życie człowieka Heideggerowsko wrzuconego w byt czy Sartrowsko wrzuconego jako byt w świat lub postmodernistycznie w przygodność nie zwalnia wszakże z wszelkiej odpowiedzialności, lecz wręcz przeciwnie - tym bardziej wymaga podmiotowego zajmowania stanowiska. Wybierając swe działania, podejmując decyzje, które uznaje za najlepsze z możliwych, człowiek dlatego, że ma poczucie wolności, rozumnie przyjmuje odpowiedzialność, zarazem kształtując swój byt i zaświadczając o jakości swego człowieczeństwa.

Niemniej jednak przeprowadzone rozważania w powziętej perspektywie aksjologicznej skłaniają do uznania, iż prawo do wolności słowa wyłącznie wtedy cokolwiek znaczy, kiedy człowiek przyjmuje odpowiedzialność, która - będąc trwale zakorzeniona w universum antroposferycznym - towarzyszy rozumnie pojętej conditio humana. Poruszanie się w labiryncie między

16 Jean Paul Sartre, „Absolutna wolność bytu ludzkiego. Wolność i odpowiedzialność”, w: Filozofia egzystencjalna. Wybrane teksty z historii filozofii, red. Leszek Kołakowski, Krzysztof Pomian (Warszawa: Wydawnictwo PWN, 1965), 346-368. 
wolnością a odpowiedzialnością za słowo uwyraźnia awers i rewers złożoności współczesnych problemów. Jakkolwiek w żadnej z dotychczasowych epok w toku dziejów relacje ludzi z otoczeniem nie kształtowały się idealnie, bezproblemowo, to jednak, pomimo kierowania pod adresem człowieka rozmaitej proweniencji zarzutów, wyłącznie z istotą ludzką można wiązać nadzieje na pokonywanie wszelkich nieprawidłowości także w odniesieniu do wolności i odpowiedzialności za słowo.

\section{In the Maze of Freedom and Responsibility of Speech (Summary)}

Freedom and responsibility constitute one of the basic issues of ethical reflection concerning ontological foundations for human activity which clearly testify to conditio humana of a human being and, especially, to the quality of his humanity. Moving around the maze between freedom and responsibility of speech emphasizes the obverse and reverse of the complexity of the contemporary problems. The deliberations in the adopted axiological perspective inclined one to recognize that the right to free speech is only of some value when a human being also takes the responsibility which - being permanently rooted in the anthroposherical universum - accompanies the rationally comprehended conditio humana.

Key words: freedom and responsibility of speech; anthropospheric universum; maze; humanity; conditio humana.

\section{W labiryncie wolności i odpowiedzialności za słowo (Streszczenie)}

Wolność i odpowiedzialność stanowią jeden z głównych problemów refleksji etycznej, dotyczących ontologicznych podstaw działalności ludzkiej ewidentnie zaświadczających o conditio humana człowieka, zwłaszcza o jakości jego człowieczeństwa. Poruszanie się w labiryncie między wolnością a odpowiedzialnością za słowo uwyraźnia awers i rewers złożoności współczesnych problemów. Rozważania w powziętej perspektywie aksjologicznej skłaniają do uznania, iż prawo do wolności słowa wyłącznie wtedy cokolwiek znaczy, kiedy człowiek przyjmuje odpowiedzialność, która - będąc trwale zakorzeniona w universum antroposferycznym - towarzyszy rozumnie pojętej conditio humana. 
Słowa kluczowe: wolność i odpowiedzialność za słowo; universum antroposferyczne; labirynt; człowieczeństwo; conditio humana.

\section{Bibliografia}

Bell, Daniel. Kulturowe sprzeczności kapitalizmu, tłum. Stefan Amsterdamski. Warszawa: Wydawnictwo PWN, 1998.

Fromm, Erich. Niech się stanie człowiek. Z psychologii etyki, tłum. Robert Saciuk. Warszawa: Wydawnictwo PWN, 1998.

Ingarden, Roman. Książeczka o człowieku. Kraków: Wydawnictwo Literackie, 1987. Kozielecki, Józef. Koniec wieku nieodpowiedzialności. Warszawa: Wydawnictwo Jacek Santorski \& Co, 1995.

Ostrowska, Urszula. „Axiological Aspects of the Word in Education”. Journal of International Scientific Publications 9 (2015), www. Scientific-publications.net.

Ostrowska, Urszula. „Problem odpowiedzialności za słowo w edukacji akademickiej". W: Odpowiedzialność jako wartość i problem edukacyjny, red. Andrzej M. de Tchorzewski, 141-168. Bydgoszcz: Wydawnictwo „WERS”, 1998.

Ostrowska, Urszula. Dialog w pedagogicznym badaniu jakościowym. Kraków: Oficyna Wydawnicza Impuls, 2000.

Ostrowska, Urszula. Doświadczanie wartości edukacyjnych w szkole wyższej. Bydgoszcz: Wydawnictwo Uczelniane Akademii Techniczno-Rolniczej w Bydgoszczy, 1998.

Parandowski, Jan. Alchemia słowa. Warszawa: Wydawnictwo Czytelnik, 1986.

Plessner, Helmuth. Pytanie o conditio humana: wybór pism, wybrał i wstępem opatrzył Zdzisław Krasnodębski, przeł. Małgorzata Łukasiewicz, Zdzisław Krasnodębski, Andrzej Załuska. Warszawa: Państwowy Instytut Wydawniczy, 1988. Sartre, Jean Paul. „Absolutna wolność bytu ludzkiego. Wolność i odpowiedzialność”. W: Filozofia egzystencjalna. Wybrane teksty z historii filozofii, red. Leszek Kołakowski, Krzysztof Pomian, 346-368. Warszawa: Wydawnictwo PWN, 1965. Seneka, Lucjusz Anneusz. Myśli, wybór, przekład i opracowanie Stanisław Stabryła. Kraków: Wydawnictwo Literackie, 1987.

Szahaj, Andrzej. Kapitalizm drobnego druku. Warszawa: Instytut Wydawniczy Książka i Prasa, 2014.

IX Ogólnopolski Zjazd Pedagogiczny 21-23 września 2016 Białystok: http://9zjazd. ptp.uwb.edu.pl/?page_id=533 - [dostęp 1.10.2015]. 